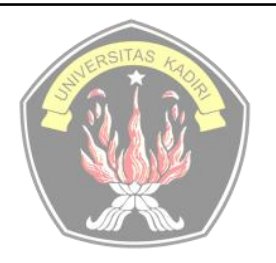

Tersedia online di

"http://ojs.unik-kediri.ac.id/index.php/ekonika"

do

http://dx.doi.org/10.30737/ekonika.v6i2.1537

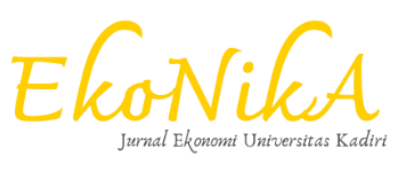

\title{
Analisis Learning Curves Industri Pengolahan Non Migas Skala Besar Dan Sedang Di Indonesia Periode Tahun 2008-2018
}

\author{
Sugiyono $^{1}$ dan Lilis Imamah Ichdayati ${ }^{2}$ \\ ${ }^{1}$ Fakultas Pascasarjana Universitas Mercu Buana Jakarta \\ ${ }^{2}$ Universitas Islam Negeri Syarif Hidayatullah Jakarta \\ email: ${ }^{1}$ sugiyono@mercubuana.ac.id, 2lilis.imamah@uinjkt.ac.id
}

\section{Artikel History:}

Artikel masuk : 01-06-2021

Artikel revisi : 26-08-2021

Artikel diterima : 29-08-2021

\section{Keywords:}

Learning Curves, Non-Oil and

Gas Processing Industry

\begin{abstract}
ABSTRAK
Penelitian ini bertujuan untuk menganalisis Kurva Pembelajaran pada industri pengolahan nonmigas skala besar dan menengah di Indonesia periode 2008-2018. Data sekunder untuk pooled type dikumpulkan dari Badan Pusat Statistik Indonesia periode 20082018. Data diolah menggunakan POM-QM for Windows versi 5.3 yang diproduksi oleh Pearson Education. Analisis data menggunakan metode deskriptif kuantitatif. Rata-rata Kurva Pembelajaran industri pengolahan nonmigas di Indonesia periode 2008-2018 sebesar 58,20 persen.
\end{abstract}

\section{ABSTRACT}

This study aims to analyze Learning Curves in large and medium scale non-oil and gas processing industries in Indonesia for the period 2008-2018. Secondary data for pooled types were collected from the Indonesian Central Bureau of Statistics for the period 2008-2018. The data was processed using POM-QM for Windows version 5.3 produced by Pearson Education. The data were analyzed using descriptive quantitative method. The average Learning Curves for the non-oil and gas processing industry in Indonesia for the 2008-2018 period was 58.20 percent.

\section{INTRODUCTION}

Learning Curves menggunakan premis bahwa orang-orang dan organisasi menjadi lebih baik dalam mengerjakan tugas mereka secara lebih baik dan lebih cepat ketika tugas-tugas itu semakin sering dikerjakan secara berulang-ulang (Heizer et al, 2017). Learning Curves pertama kali dipraktekkan oleh T. P. Wright dari Curtis-Wright Corp pada tahun 1936 (Heizer et al, 2017). Wright menjelaskan bahwa biaya tenaga kerja yang digunakan untuk memproduksi sebuah pesawat terbang menjadi semakin lebih murah dengan semakin sering dilakukannya kegiatan pembelajaran.

Learning Curves ternyata berlaku juga untuk berbagai kategori kerangka udara dari pesawat jet tempur, pesawat penumpang, dan pesawat pengebom. Learning Curves kemudian 
dalam perjalanan waktu dipraktekkan juga untuk mempelajari perilaku-perilaku tenaga kerja, bahan dan komponen yang dibeli, tingkat pekerjaan, biaya, kapasitas, dan harga sejalan dengan kegiatan yang sama, namun kegiatan tadi kemudian dikerjakan secara berulang-ulang.

Industri pengolahan di Indonesia secara umum dibedakan menjadi industri batubara dan pengilangan migas dengan industri pengolahan non migas (Gambar 1). Fenomena gap yang terjadi pada industri pengolahan non migas berupa fenomena deindustrialisasi, yaitu laju pertumbuhan industri pengolahan non migas menunjukkan sedang mengalami penurunan. Penurunan tersebut kemudian mencapai puncak dengan berubah menjadi negatif pada tahun 2020. Penurunan pertumbuhan industri pengolahan non migas terjadi, karena terjadinya krisis ekonomi yang dipicu oleh serangan pandemic Covid-19. Berbeda halnya dengan industri pengolahan non migas yang menurun, pada industri batu bara dan pengilangan migas terjadi volatilitas pertumbuhan ekonomi.

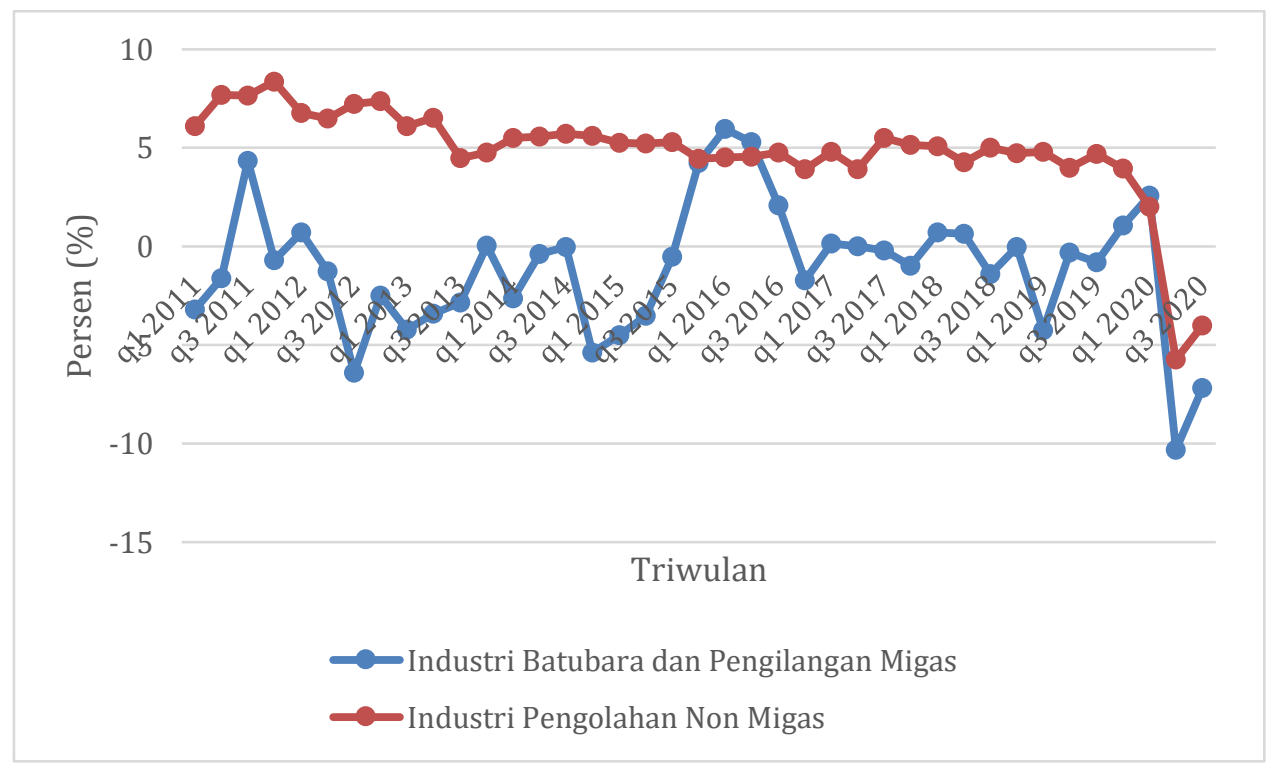

Gambar 1. Pertumbuhan Industri Batubara dan Pengilangan Migas serta Industri Pengolahan Non Migas Indonesia Periode Triwulan I Tahun 2011 - Triwulan III Tahun 2020, year on year, Harga Konstan Tahun 2010

Sumber: www.bps.go.id, 2021

Menurut Mankiw (2015), konsep pertumbuhan ekonomi adalah perkembangan dari nilai output pada harga konstan. Nugroho (2017) mengatakan bahwa pertumbuhan ekonomi menunjukkan kesejahteraan. Untuk melakukan pendalaman tentang mengapa terjadi laju pertumbuhan ekonomi yang menurun pada industri pengolahan non migas, maka dicari penjelasan tentang apakah terjadi pelambatan dalam learning curves pada industri pengolahan non migas di Indonesia. Oleh karena itu, disusun perumusan masalah penelitian sebagai berikut: 
Indonesia periode 2008-2018 mengalami perlambatan?

Berdasarkan latar belakang masalah dan perumusan masalah penelitian tersebut di atas, maka penelitian ini bertujuan untuk:

1. Menganalisis kinerja Learning Curves pada industri pengolahan non migas skala besar dan sedang di Indonesia periode tahun 2008-2018.

2. Menganalisis kinerja industri pengolahan non migas skala besar dan sedang di Indonesia periode tahun 2008-2018, yang tidak mengikuti pola perilaku Learning Curves.

\section{LITERATURE REVIEW}

Learning Curves didasarkan pada kejadian penggandaan produksi (Heizer et la, 2017). Ketika produksi mengalami kejadian berlipat ganda, maka penurunan waktu per unit akan mempengaruhi kondisi keberadaan laju Learning Curves. Jika Learning Curves teridentifikasi sebesar 80 persen, maka produksi pada unit kedua menghabiskan sebanyak 80 persen dari waktu yang diperlukan untuk berproduksi 2 kali lipat banyaknya dibandingkan terhadap banyaknya waktu yang dierlukan untuk memproduksi unit yang sama pada waktu yang pertama. Produksi unit keempat menghabiskan sebanyak 80 persen dari waktu yang diperlikan dibandingkan waktu untuk menjadi 2 kali lipat dibandingkan unit yang kedua. Produksi unit kedelapan menghabiskan sebanyak 80 persen dari waktu unit keempat untuk dapat menghasilkan produksi sebanyak 2 kali lipat dari produksi sebelumnya, dan demikian kondisi yang seperti ini terjadi secara berulang terus-menerus.

Prinsip kejadian secara berulang tersebut di atas, kemudian dinyatakan ke dalam bentuk persamaan secara matematika sebagai berikut:

$\mathrm{T} \times \mathrm{L}^{\mathrm{n}}=$ waktu yang dibutuhkan untuk memproduksi unit yang ke-n.

dimana: $\mathrm{T}=$ biaya unit atau waktu unit dari unit pertama.

$\mathrm{L}=$ laju Learning Curves.

$\mathrm{n}=$ jumlah unit untuk menggandakan $\mathrm{T}$.

Jika unit pertama dari produk tertentu memakan waktu 10 jam kerja, dan jika Learning Curves sebesar 70 persen, maka jam unit keempat akan membutuhkan penggandaan dua kali yaitu dari 1 menjadi 2 kali lipat kemudian dari 2 menjadi 4. Dengan demikian, semakin besar angka Learning Curves, maka diperlukan waktu pembelajaran yang semakin lama untuk meningkatkan volume produksi menjadi dua kali lipat. Sebaliknya, dengan semakin kecil angka 
Learning Curves, maka diperlukan waktu pembelajaran yang semakin singkat untuk meningkatkan volume produksi menjadi dua kali lipat dari semula.

Learning Curves berguna untuk memperkirakan persyaratan jam kerja suatu produk. Informasi tentang agen pembelian dapat digunakan untuk menentukan biaya pemasok dan negosiasi harga. Aplikasi penting lainnya dari Learning Curves adalah dalam kegiatan perencanaan yang bersifat strategis, yaitu untuk mempercepat Learning Curves, sehingga daya saing suatu produk menjadi semakin meningkat. Meskipun demikian, keterbatasan Learning Curves (Heizer et al, 2017) adalah sebagai berikut: (1) Learning Curves berbeda dari perusahaan ke perusahaan yang lain, serta berbeda diantara industri ke industri yang lainnya, (2) pengukuran Learning Curves musti valid, (3) setiap perubahan dalam personel, desain, atau prosedur dapat mengubah besarnya angka pencapaian Learning Curves, (3) Learning Curves yang sama tidak akan selalu berlaku untuk tenaga kerja dan bahan baku yang bersifat secara tidak langsung, dan (4) keberadaan budaya kerja, ketersediaan sumber daya dan perubahan dalam suatu proses produksi, diperkirakan akan dapat mengubah besar pencapaian suatu Learning Curves.

Kebaruan pada penelitian ini adalah menghitung Learning Curves rate pada industri pengolahan non migas di Indonesia periode tahun 2008-2018 dalam KBLI 3 digit untuk industri berskala besar dan sedang, sedangkan penelitian yang lain dikemukakan di bawah ini berupa menghitung Learning Curves pada subsektor industri pengolahan non migas tertentu saja, yang bersifat terbatas. Disamping itu yang bersifat baru pada penelitian ini adalah adanya penggunaan banyak jumlah perusahaan sebagai sampel penelitian. Selanjutnya, kajian empiris dari hasil penelitian disajikan secara ringkas di bawah ini.

Barber (2011) mengatakan bahwa ketika jumlah produk yang dihasilkan berlipat ganda, maka kegiatan biaya yang berulang per unit menunjukkan perilaku yang berkurang pada tingkat yang tetap, atau persentase menunjukkan konstan. Learning curves menurut Barber (2011) diperoleh dapat berasal dari pengamatan aktual dari jalur produksi, atau dengan menggunakan analogi pada sistem yang serupa, yang sebelumnya telah diproduksi. Lebih lanjut, Teplitz (2014) mengatakan bahwa peneliti yang telah mengetahui tentang cara menghitung Learning Curves menjadi sangat penting dalam memperkirakan waktu dan biaya produksi di masa depan. Makalah Tepliz (2014) membahas tentang bagaimana menentukan secara efektif dampak dari peristiwa dan bagaimana membuat perubahan pada perkiraan di masa depan dengan menggunakan learning curves. 
Anzanello dan Flogiarto (2011) mengatakan bahwa model Learning Curves dapat digunakan dalam berbagai aplikasi industri, dimana para pekerja berusaha untuk mengerjakan tugas-tugas yang baru. Pemodelan Learning Curves menurut Anzanello dan Flogiarto (2011) memungkinkan penugasan tugas yang lebih baik kepada pekerja dan perencanaan produksi yang lebih efisien, dan mengurangi biaya produksi.

Hasil penelitian EPA (2016) menunjukkan bahwa untuk sebagian besar komponen, biaya produksi menunjukkan perilaku yang cenderung menurun dengan semakin meningkatnya volume produksi dan dengan terjadinya adanya akumulasi pengalaman. Sabrina dan Diawati (2012) mengatakan bahwa model learning curves yang diamati pada assembling line menunjukkan kapasitas aktual lebih rendah dari kapasitas yang dirancang, karena adanya kendala di sepanjang produksi, seperti keterlambatan pasokan komponen, errror peralatan, dan cacat produk. Untuk memaksimalkan pemanfaatan kapasitas yang dirancang, lini dari asssembly line harus meningkatkan kemampuannya berdasarkan dukungan yang kuat dari departemen lain, seperti departemen-departemen pengadaan, pemeliharaan, kualitas, pengelasan, dan pengecatan. Hasil penelitian dari Sabrina dan Diawati (2012) tersebut menjelaskan tentang faktor-faktor yang dapat menentukan besar angka Learning Curves.

Hossain (2014) mengatakan bahwa penurunan harga pada banyak produk elektronik konsumen konsisten dengan kondisi keberadaan Learning Curves dari produksi kumulatif. Feriyanto et al (2015) mengatakan bahwa stasiun jahit omo tape membutuhkan operator lain sebagai tenaga kerja tambahan, dimana Learning curves rate diperoleh sebesar 91,59 persen.

Samadi (2017) mengatakan bahwa untuk beberapa teknologi pembangkit listrik, terutama teknologi modular skala kecil, telah ada hubungan negatif yang sangat kuat antara pengalaman dan biaya selama beberapa dekade. Sebaliknya, untuk teknologi berskala besar dan sangat kompleks, maka Learning Curves tidak menjadi alat yang cukup berguna untuk menjelaskan tentang perubahan biaya dari waktu ke waktu. Apa yang disampaikan oleh Samadi (2017) telah mampu menjelaskan tentang adanya keterbatasan dari Learning Curves. Heng (2010) mengatakan bahwa kurangnya sumberdaya alam di Singapura dan basis domestik kecil, maka keterbatasan tersebut membuat tidak ada alasan Singapura untuk penargetan industri. Dengan adanya estimasi Learning Curves, kemudian telah mengonfirmasi tentang keberadaan industri tekstil yang lemah, sehingga Singapura kemudian melakukan diversifikasi industri dari industri tekstil ke industri elektronik, kulit dan produk kayu.

Rajibussalim et al (2014) mengatakan bahwa penempatan kerja telah meningkatkan kesiapan siswa untuk memasuki tempat kerja dan meningkatkan keterampilan, pengetahuan, 
dan pengalaman siswa di bidang-bidang tertentu. Learning Curves di tempat kerja menawarkan kesempatan bagi universitas-universitas untuk mempersiapkan lulusan yang lebih siap untuk bekerja pada lulusan yang lebih memiliki pengetahuan, keterampilan, dan pengalaman di dunia industri. Kemudian pada saat yang sama, para alumni universitas berkontribusi untuk membantu memecahkan masalah-masalah yang terkait dengan masalah-masalah yang ada pada sektor industri.

Meinanda dan Hadi (2014) mengatakan bahwa penerapan Learning Curves pada kegiatan organisasi di PT. XYZ dipengaruhi oleh budaya lokal. Terdapat beberapa kendala dalam menerapkan learning organization, menurut Meinanda dan Hadi (2014) seperti kurangnya ketersediaan posisi dalam penempatan lulusan program pengembangan dan karakter masyarakat sekitar juga menjadi salah satu kendala dalam melakukan kegiatan learning organization.

Kim dan Lee (2018) mengatakan bahwa trend dalam inovasi teknologi memiliki hubungan dengan kegiatan produksi. Studi ini menghitung Learning Curves pada 30 perusahaan dari industri eksplorasi dan produksi minyak di Amerika Serikat. Learning Curves tadi mencerminkan perubahan dalam rasio produksi minyak. Hasil perhitungan Kim dan Lee (2018) menunjukkan bahwa interpretasi kegiatan produksi strategis berhubungan secara statistik dengan perubahan lingkungan industri. Berends dan Antocepoulou (2013) mengatakan bahwa waktu pembelajaran organisasi, peran masa lalu, sekarang, dan masa depan dibedakan dalam kegiatan learning organization. Masing-masing dari perspektif ini menawarkan wawasan yang unik, yang ketika terintegrasi dapat membantu memetakan arah baru untuk penelitian masa depan. Lapre dan Nembhard (2010) kemudian mengatakan bahwa Learning Curves organisasi untuk mengetahui proses kegiatan dari pembelajaran organisasi.

Lee (2014) mengatakan bahwa banyak faktor yang dapat menentukan kemiringan Learning Curves untuk individu, tim, pabrik atau industri tertentu. Di antara ini adalah: gaya dan tindakan, manajemen, budaya perusahaan, struktur organisasi, teknologi, modal investasi, dan teknik. Kuncoro (2012) mengatakan bahwa dampak perusahaan investasi asing (Foeign Direct Investment, FDI) pada Research and Development (R\&D) domestik terjadi hanya pada insiden, bukan pada intensitas dari kegiatan R\&D. Hasil penelitian dari Kuncoro (2012) tersebut akan membutuhkan banyak perusahaan dalam lokasi, atau aglomerasi untuk memiliki dampak yang berarti.

Berdasarkan kajian teori dan kajian empiris tersebut di atas, maka disusun kerangka pemikiran pada Gambar 2. Data industri pengolahan non migas skala besar dan sedang periode 

nilai tambah per tahun per KBLI untuk diolah secara sederhana menjadi rasio tenaga kerja per nilai tambah. Rasio tersebut dimasukkan ke dalam software POM QM for Windows dan diperoleh laju Learning Curves.

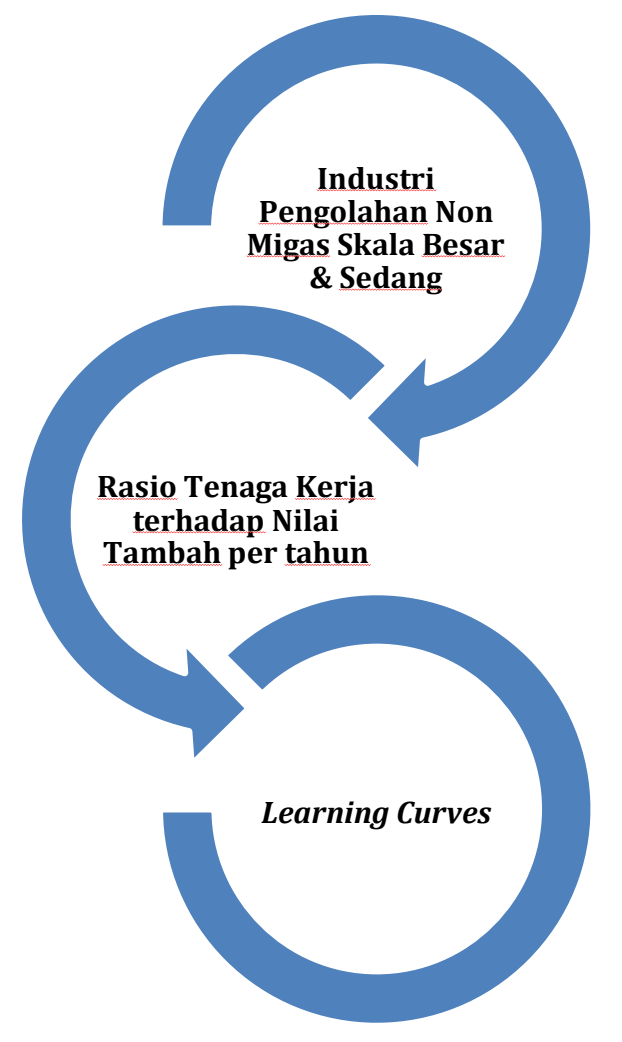

Gambar 2. Kerangka Pemikiran Learning Curves

\section{METHODS}

Penelitian ini menggunakan metode penelitian kuantitatif deskriptif. Metode penelitian kuantitatif deskriptif merupakan pilihan metode penelitian selain menggunakan penelitian kuantitatif inferensia, kualitatif, mix methods, serta metode eksperimen. Digunakannya metode penelitian kuantitatif deskriptif, karena metode penelitian ini relatif mudah diaplikasikan untuk berbagai jenis penelitian pada bidang konsentrasi manajemen produksi dan operasi.

Tabel 1. Operasionalisasi Variabel

\begin{tabular}{lll}
\hline Variabel & Definisi & Skala Pengukuran \\
\hline Tenaga Kerja & $\begin{array}{l}\text { Banyaknya tenaga kerja industri besar } \\
\text { dan sedang KBLI 3 digit (orang) }\end{array}$ & Rasio \\
& $\begin{array}{l}\text { Tahun } \\
\text { Waktu }\end{array}$ & Rasio \\
Nilai Tambah & $\begin{array}{l}\text { Nilai tambah industri besar dan sedang } \\
\text { KBLI 3 digit (Rp Milyar) }\end{array}$ & Rasio \\
\hline
\end{tabular}

Sumber: BPS, 2021. 
Data sekunder yang digunakan berasal dari laporan data terbitan Badan Pusat Statistik di Indonesia. Data sekunder tersebut disusun oleh Badan Pusat Statistik dari populasi industri skala besar dan sedang di Indonesia yang berjumlah sebanyak 30115 perusahaan untuk tahun 2018. Jumlah sampel yang digunakan pada penelitian ini sebanyak jumlah populasi, yaitu sebanyak 30115 perusahaan untuk tahun 2018.

Metode pengumpulan data yang digunakan adalah metode eksplorasi data sekunder. Data sekunder berasal dari laporan statistik industri manufaktur periode tahun 2008-2018 (BPS, 2013-2020). Data yang dikumpulkan berasal dari Klasifikasi Baku Lapangan Usaha Indonesia (KBLI) 3 digit (BPS, 2020).

Metoda pengolahan data menggunakan software POM-QM for Windows versi 5,3. Software tersebut diproduksi oleh Pearson (Weiss, 2018). Metoda analisis data menggunakan metode kuantitatif deskripti. Metoda pengolahan data diawali dengan membuat data pool urutan waktu, yang menggunakan cross section berupa kode industrl KBLI 3 digit dari data jumlah tenaga kerja industri per tahun per KBLI. Demikian pula untuk data nilai tambah industri. Selanjutnya, dilakukan pembagian antara data jumlah tenaga kerja dibagi dengan data nilai tambah. Data tahun 2008 dijadikan sebagai data tahun dasar. Data tahun 2018 dijadikan sebagai data ke-n. Data hasil pengolahan POM QM for Windows disajikan dalam bentuk tabel untuk dianalisis. Data yang tidak cocok dengan perilaku Learning Curves dicatat, yaitu jika data rasio tenaga kerja dengan nilai tambah pada tahun ke-n yang lebih besar dibandingkan pada tahun dasar. Pembahasan disajikan menggunakan hasil penelitian dan diperbandingkan dengan perolehan Learning Curves dari hasil penelitian terdahulu.

Tabel 2. Kode Baku Lapangan Usaha Indonesia 3 Digit untuk Industri Pengolahan Non Migas Kode Nama Industri Industri

$101 \quad$ Industri pengolahan dan pengawetan daging

102 Industri pengolahan dan pengawetan ikan dan biota air

103 Industri pengolahan dan pengawetan buah-buahan dan sayuran

104 Industri minyak makan dan lemak nabati dan hewani

105 Industri pengolahan susu, produk dari susu dan es krim

106 Industri penggilingan padi-padian, tepung dan pati

107 Industri makanan lainnya

108 Industri makanan hewan

110 Industri minuman

120 Industri pengolahan tembakau

131 Industri pemintalan, penenunan dan penyelesaian akhir tekstil

139 Industri tekstil lainnya

141 Industri pakaian jadi dan perlengkapannya, bukan pakaian jadi dari kulit berbulu

143 Industri pakaian jadi rajutan dan sulaman/border 
151 Industri kulit dan barang dari kulit, termasuk kulit buatan

152 Industri alas kaki

161 Industri penggergajian dan pengawetan kayu, rotan, bambu dan sejenisnya

162 Industri barang dari kayu, industri barang dari gabus dan barang anyaman dari jerami, rotan, bamboo dan sejenis lainnya

170 Industri kertas dan barang dari kertas

181 Industri pencetakan dan kegiatan ybdi

182 Reproduksi media rekaman

191 Industri produk dari batu bara

192 Industri produk pengilangan minyak bumi

201 Industri bahan kimia

202 Industri barang kimia lainnya

203 Industri serat buatan

210 Industri farmasi, produk obat kimia dan obat tradisional

221 Industri karet dan barang dari karet

222 Industri barang dari plastic

231 Industri kaca dan barang dari kaca

239 Industri barang galian bukan logam lainnya

241 Industri logam dasar besi dan baja

242 Industri logam dasar mulia dan logam dasar bukan besi lainnya

243 Industri pengecoran logam

251 Industri barang logam siap pasang untuk bangunan, tangka, tandon air dan generator uap

259 Industri barang logam lainnya dan jasa pembuatan barang logam

$261 \quad$ Komponen dan papan elektronik

262 Industri computer dan perlengkapnnya

263 Industri peralatan komunikasi

264 Industri peralatan audio dan video elektronik

265 Industri alat ukur, alat uji, peralatan navigasi dan kontrol dan alat ukur waktu

266 Industri peralatan iradiasi, elektromedikal dan elektroterapi

267 Industri peralatan fotografi dan instrumen optik bukan kaca mata

268 Media magnetik dan media optic

271 Industri motor listrik, generator, transformator dan peralatan pengontrol dan pendistribusian listrik

$272 \quad$ Industri batu baterai dan akumulator listrik

273 Industri kabel dan perlengkapannya

274 Industri peralatan penerangan listrik termasuk peralatan penerangan bukan listrik

275 Industri peralatan rumah tangga

279 Industri peralatan lainnya

281 Industri mesin untuk keperluan umum

282 Industri mesin untuk keperluan khusus

291 Industri kendaraan bermotor roda empat atau lebih

292 Industri karoseri kendaraan bermotor roda empat atau lebih dan industri trailer dan semi trailer

293 Industri suku cadang dan aksesori kendaraan bermotor roda empat atau lebih

$301 \quad$ Industri pembuatan kapal dan perahu

309 Industri angkutan lainnya

$310 \quad$ Industri furniture

321 Industri barang perhiasan dan barang berharga 


\begin{tabular}{cl}
\hline Kode & \\
Industri & \\
\hline 322 & Industri alat musik \\
323 & Industri alat olah raga \\
324 & Industri alat permainan dan mainan anak-anak \\
325 & Industri peralatan kedokteran dan kedokteran gigi serta perlengkapannya \\
329 & Industri pengolahan lainnya \\
331 & Jasa reparasi produk logam pabrikasi, mesin dan peralatan
\end{tabular}

Sumber: BPS, 2020.

\section{RESULTS}

Hasil penelitian ini, pertama, adalah rata-rata pada industri pengolahan non migas di Indonesia periode tahun 2008-2018 sebesar 58,2 persen (Tabel 3). Rata-rata Learning Curves pada industri pengolahan non migas di Indonesia tahun 2008-2018 tersebut di atas lebih rendah dibandingkan dengan Learning Curves dari mobil produksi Ford yang sebesar 86 persen, perakitan pesawat yang sebesar 80 persen, pemeliharaan peralatan perusahaan General Electric yang sebesar 76 persen, produksi baja yang sebesar 79 persen, integrated circuits yang sebesar 72 persen, kalkulator sebesar 74 persen, disk memory drives sebesar 76 persen, dan transplantasi hati yang sebesar 79 persen (Heizer and Render, 2017). Rendahnya rata-rata nilai Learning Curves di atas dan lebih rendah dibandingkan rujukan pembanding menunjukkan bahwa persoalan deindustrialisasi tidak dapat dijelaskan menggunakan fenomena Learning Curves, kecuali untuk beberapa industri yang mempunyai Learning Curves tinggi, yaitu: Industri pengolahan dan pengawetan daging, Industri pakaian jadi rajutan dan sulaman/border, dan Industri angkutan lainnya.

Tabel 3. Hasil Perhitungan Learning Curves pada Industri Pengolahan Non Migas di Indonesia Periode Tahun 2008-2018

\begin{tabular}{rrrrrr} 
Kode_Industri & Learnining Curves & Kode_Industri & Learnining Curves & Kode_Industri & Learnining Curves \\
\hline 101 & 0.9025 & 192 & 0.7113 & 271 & 0.4479 \\
102 & 0.6678 & 201 & 0.6783 & 272 & 0.7877 \\
103 & 0.7408 & 202 & 0.7044 & 273 & 0.6474 \\
104 & 0.8154 & 203 & na & 274 & 0.5482 \\
105 & 0.5775 & 210 & na & 275 & 0.7345 \\
106 & 0.7012 & 221 & 0.7770 & 279 & 0.3752 \\
107 & 0.6164 & 222 & na & 281 & 0.6213 \\
108 & 0.8089 & 231 & 0.4083 & 282 & 0.6222 \\
110 & 0.7691 & 239 & 0.7010 & 291 & na \\
120 & 0.7438 & 241 & 0.8005 & 292 & 0.5815 \\
131 & 0.7141 & 242 & 0.7800 & 293 & 0.6211 \\
139 & 0.6956 & 243 & 0.5870 & 301 & 0.8625 \\
141 & 0.5939 & 251 & 0.1932 & 309 & 0.9858 \\
143 & 0.9699 & 259 & na & 310 & 0.6533
\end{tabular}




\begin{tabular}{rrrrrr} 
Kode_Industri & Learnining Curves & Kode_Industri & Learnining Curves & Kode_Industri & Learnining Curves \\
\hline 151 & 0.6071 & 261 & 0.7240 & 321 & 0.6548 \\
152 & 0.6617 & 262 & 0.8414 & 322 & 0.6285 \\
161 & 0.6498 & 263 & 0.5784 & 323 & na \\
162 & 0.7530 & 264 & na & 324 & 0.7939 \\
170 & 0.6894 & 265 & na & 325 & 0.5422 \\
181 & 0.6280 & 266 & 0.4662 & 329 & 0.6605 \\
182 & 0.5880 & 267 & 0.6906 & 331 & 0.6266 \\
191 & $\mathrm{Na}$ & 268 & 0.8883 & Rata-rata & 0.5820 \\
\hline
\end{tabular}

Sumber: Hasil Pengolahan Data, 2021

Kedua, perilaku Learning Curves tidak dijumpai pada beberapa KBLI (Tabel 3), karena nilai rasio antara jumlah tenaga kerja dengan nilai tambah pada tahun ke-11, yaitu tahun 2018, bernilai lebih besar dibandingkan nilai rasio tersebut pada tahun dasar 2008. Industri yang perilaku Learning Curves tergolong tidak teridentifikasi dengan baik sesuai keberadaan teori Learning Curves pada industri pengolahan non migas periode tahun 2008-2018 adalah sebagai berikut: (1) Industri kendaraan bermotor roda empat atau lebih, (2) Industri serat buatan, (3) Industri farmasi, produk obat kimia dan obat tradisional, (4) Industri barang dari plastik, (5) Industri barang logam lainnya dan jasa pembuatan barang logam, (6) Industri peralatan audio dan video elektronik, (7) Industri alat ukur, alat uji, peralatan navigasi dan kontrol dan alat ukur waktu, (8) Industri kendaraan bermotor roda empat atau lebih, dan (9) Industri alat olah raga. Hasil penelitian pada kesembilan KBLI di atas (Tabel 3) tidak selalu cocok dibandingkan dengan penelitian dari Barber (2011), Anzanello dan Flogiarto (2011), EPA (2016), Sabrina dan Diawati (2012), Hossain (2014), Feriyanto et al (2015), dan Samadi (2017).

Ketiga, Learning Curves terendah dijumpai pada Industri barang logam siap pasang untuk bangunan, tangka, tandon air dan generator uap (KBLI 251), yaitu sebesar 19,32 persen. Learning Curves yang rendah menunjukkan bahwa industry tersebut memerlukan waktu yang lebih pendek untuk menghasilkan nilai tambah per tenaga kerja dapat meningkat dua kali lipat dari tahun dasar. Keempat, Learning Curves tertinggi terdapat pada Industri angkutan lainnya (KBLI 309), yang sebesar 98,58 persen.

\section{CONCLUSION AND SUGGESTION}

Berdasarkan hasil dan pembahasan tersebut di atas, disusun kesimpulan sebagai berikut:

1. Learning Curves secara umum ditemukan terjadi pada industri pengolahan non migas skala besar dan sedang di Indonesia periode tahun 2008-2018 dengan nilai rata-rata tergolong sedang. 
2. Perilaku Learning Curves tidak ditemukan pada sembilan industri pengolahan non migas skala besar dan sedang di Indonesia periode tahun 2008-2018, yaitu (1) Industri kendaraan bermotor roda empat atau lebih, (2) Industri serat buatan, (3) Industri farmasi, produk obat kimia dan obat tradisional, (4) Industri barang dari plastik, (5) Industri barang logam lainnya dan jasa pembuatan barang logam, (6) Industri peralatan audio dan video elektronik, (7) Industri alat ukur, alat uji, peralatan navigasi dan kontrol dan alat ukur waktu, (8) Industri kendaraan bermotor roda empat atau lebih, dan (9) Industri alat olah raga.

Saran untuk penelitian lanjutan adalah diperlukan penelitian secara mikro untuk mengetahui tentang bagaimana menurunkan besarnya Learning Curves yang masih relatif tinggi pada industri pengolahan non migas di Indonesia tertentu, maupun disagregasi dari kesembilan industri KBLI yang tidak mengikuti perilaku Learning Curves.

\section{BIBLIOGRAPHY}

Anzanello, M.J. and F.S. Fogliatto. 2011. Learning Curve Models and Applications: Literature Review and Research Directions. International Journal of Industrial Ergonomics:41 (2011) 573-583.

Barber, E. 2011. Application of Learning Curve Theory to Systems Acquisition. Defense Acquisition University: Business, Cost Estimating and Financial Management Department.

Berends, H. and E. Antonacopoulou. 2013. Time and Organizational Learning: A Review and Agenda for Future Research. International Journal of Management Reviews. November 2013.

BPS [Badan Pusat Statistik]. 2013. Indikator Industri Manufaktur 2011. Badan Pusat Statistik, Jakarta. 2014. Indikator Industri Manufaktur 2012. Badan Pusat Statistik, Jakarta. 2015. Indikator Industri Manufaktur 2013. Badan Pusat Statistik, Jakarta. 2016. Indikator Industri Manufaktur 2014. Badan Pusat Statistik, Jakarta. 2017. Indikator Industri Manufaktur 2015. Badan Pusat Statistik, Jakarta. 2019. Indikator Industri Manufaktur 2017. Badan Pusat Statistik, Jakarta. 2019a. Berita Resmi Statistik: Pertumbuhan Ekonomi Indonesia Triwulan III-2019. No. 89/11/Th.XXII, 5 November 2019. Badan Pusat Statistik, Jakarta. 2020. Indikator Industri Manufaktur 2018. Badan Pusat Statistik, Jakarta.

EPA and RTI International. 2016. Cost Reduction through Learning in Manufacturing Industries and in the Manufacture of Mobile Sources: Final Report and Peer Review Report. Assesment and Standards Division Office of Transportation and Air Quality U.S. Environmental Protection Agency. EPA-420-R-16-018, November 2016.

Feriyanto, N., C. Saleh, H.M. Badri, B.Md. Deras, and Y. Pratama. 2015. Implementation Learning and Forgetting Curve to Predict Needs and Decrease of Labors Performance After Break. Jurnal Teknologi: 77:27(2015)135-140.

Heizer, J., B. Render, and C. Munson. 2017. Operations Management: Sustainability and Supply Chain Management. Pearson, Boston.

Heng, T.H. 2010. Learning Curves \& Productivity in Singapore Manufacturing Industries. Paper presented at the Second Annual Conference of the Academic Network for Development in Asia (ANDA), Pnom Penh, Cambodia, 8-10 January 2010.

Johnstone, B.M. 2015. Improvement Curves: An Early Production Methodology. Lockheed Martin Corporation. 
Killingsworth, P.S. 2015. An Exploratory Parametric Analysis of Production Cost Improvement in the Aerospace Industry. The Society of Cost Estimating and Analysis.

Kim, J.H. and Y.G. Lee. 2018. Learning Curve, Change in Industrial Environment, and Dynamics of Production Activities in Unconventional Energy Resources. Sustainability 2018, 10, 3322; doi:10.3390/su10093322.

Kuncoro, A. 2012. Globalization and Innovation on Indonesia: Evidence from Micro-Data on Medium and Large Manufacturing Establishments. Eria Discussion Paper series. ERIA-DP-2012-09.

Lapre, M.A. and I.M. Nembhard. 2010. Inside the Organizational Learning Curve: Understanding the Organizational Learning Process. Technology, Information and Operation Management Vol 4, No.1(2020) 1-103.

Lee, Q.P.E. 2014. Learning \& Experience Curves in Manufacturing. Strategos, Kansas City.

Mankiw, N.G. 2015. Priciples of Economics, 7e. Cengange Learning, Stamford. www.cengangebrain.com.

Meinanda, L.P. and C. Hadi. 2015. Penerapan Learning Organization pada PT XYZ. Departemen Psikologi Industri dan Organisasi Fakultas Psikologi Universitas Airlangga, Surabaya.

Nugroho, R.E. 2017. Analisis Faktor-Faktor Yang Mempengaruhi Pertumbuhan Ekonomi di Provinsi Banten. Journal of Industrial Engineering and Management Systems. Vol. 10, No. 1, February 2017.

Rajibussalim, T. Sahama, and H. Pillay. 2014. Enhancing the Learning Experiences Through IndustryBased Learning from Indonesia University Perspective.

Samadi, S. 2017. The Experience Curve Theory and Its Application in the Field of Electricity Generation Technologies. Wuppertal Institute. Renewable \& Sustainable Energy Reviews, 82(2018), 3, 2346-2364. DOI:10.1016/j.rser.2017.08.077.

Sebrina and L. Diawati. 2012. The Impact of Learning on Assembly Line Capasity: A Case Study of an Indonesia Car Factory. IEEE:978-1-4673-01-7/12.

Steven, G. 2012. The Learning Curve, The Key to Future Management. Chartered Institute of Management Accountants. Vol.6, Issue 12.

Teplitz, C.J. 2014. Learning Curve Setbacks: You Don't Always Move Down a Learning Curve. Journal of Applied Business and Economics Vol 16(6) 2014.

Weiss, H. J. 2018. POM-QM for Windows Version 5, Software for Decision Sciences: Quantitative Methods, Production and Operations Management. Pearson Education. www.pearsonhighered.com/weiss and dsSoftware@pearson.com. 